FOLIA POMERANAE UNIVERSITATIS TECHNOLOGIAE STETINENSIS

Folia Pomer. Univ. Technol. Stetin., Oeconomica 2018, 342(90)1, 71-80

Jadwiga ZARÓD

\title{
DETERMINANTY CEN NASION ROŚLIN OLEISTYCH I OLEJU ROŚLINNEGO W UNII EUROPEJSKIEJ
}

\author{
FACTORS INFLUENCING THE PRICE OF OILSEEDS \\ AND VEGETABLE OIL IN THE EUROPEAN UNION
}

Katedra Zastosowań Matematyki w Ekonomii, Zachodniopomorski Uniwersytet Technologiczny w Szczecinie, ul. Klemensa Janickiego 31, 71-270 Szczecin, e-mail: jzarod@zut.edu.pl

\begin{abstract}
Summary. Prices of agri-food products on the European Union markets are shaped by supplydemand, structural and cyclical factors. The aim of this article is to study how the supply-demand factors influence on the purchase price of oilseeds and vegetable oil in the European Union and to determine the development direction of these prices. The implementation of this aim enabled the multi-equation econometric model. Using the trends, the development directions of the prices of agri-food products were determined and their forecasts were estimated. The empirical basis for the study was data from OECD and FAO for 2004-2016. The results of the study show the high relationship between the price of selected products and factors related to production, consumption and foreign trade. On the other hand, trends show that the prices of these products increased until 2011/2012, and after that they showed a downward trend. Forecasts predict further fall in prices.
\end{abstract}

Słowa kluczowe: ceny produktów rolno-spożywczych, czynniki podażowo-popytowe, modele wielorównaniowe, modele trendów.

Key words: prices of agri-food products, supply-demand factors, multi-equation models, trend models.

\section{WSTĘP}

Ceny wielu produktów rolno-żywnościowych kształtują zarówno czynniki podażowo-popytowe, jak i czynniki o charakterze strukturalnym i koniunkturalnym. Czynniki podażowo-popytowe związane są głównie z produkcją, konsumpcją i handlem zagranicznym produktami rolno-spożywczymi. Według Hajdukiewicza (2014) czynniki strukturalne to:

- zwiększenie światowej populacji ludności,

- wysokie stopy wzrostu gospodarczego krajów rozwijających się,

- zmiany wzorców żywieniowych w krajach rozwijających się,

- nieznaczny wzrost produkcji żywności w okresie ostatnich 20 lat,

- rosnące nakłady produkcyjne oraz koszty transportu,

- powstanie nowych rynków zbytu, a zwłaszcza rynku biopaliw.

Natomiast czynniki koniunkturalne tworzą:

- anomalie pogodowe,

- zmiany kursów walutowych, 
- spekulacje finansowe i dywersyfikacje portfeli inwestycyjnych,

- koniunkturalne wahania cen ropy naftowej,

- restrykcje handlowe i gospodarcze (cła, kontyngenty taryfowe, subsydia eksportowe).

Czynniki podażowo-popytowe są ściśle powiązane z czynnikami strukturalnymi i koniunkturalnymi. Przykładowo: produkcja wzrasta wraz z powstawaniem nowych rynków zbytu, a konsumpcja przy zwiększającej się liczbie ludności. Niekorzystne warunki pogodowe wpływają na zmniejszenie plonów, a opłacalność handlu zagranicznego zależy między innymi od kursów walut.

Wpływ poszczególnych czynników na cenę produktów rolno-żywnościowych był przedmiotem wielu badań. O relacjach pomiędzy ceną żywności a wzrastającą liczbą ludności na świecie pisał Miegel (2008). Według Stępnia (2011) w krajach rozwijających się zmieniają się wzorce żywnościowe i dynamicznie wzrasta popyt na żywność, a wraz z nim rosną ceny na produkty rolne. Badaniem związku między ceną artykułów rolno-żywnościowych a produkcją biopaliw zajmował się Schmitz (2013). Natomiast Baffes i Dennis (2013) dowodzili, że wśród wybranych czynników głównie ceny ropy naftowej są odpowiedzialne za zmiany cen surowców rolnych w analizowanym przez nich okresie. Opinie ekspertów na temat wpływu spekulacji finansowych na ceny produktów rolno-żywnościowych przedstawiła Zawojska (2011).

Celem tego artykułu jest określenie wpływu czynników podażowo-popytowych na cenę skupu nasion roślin oleistych i oleju roślinnego w Unii Europejskiej oraz wyznaczenie kierunku rozwoju tych cen. Znaczeniem czynników podażowo-popytowych na kształtowanie się cen produktów rolnych zajmowali się między innymi: Hamulczuk i in. (2012), Jerzak i Łąkowski (2013), Bełdycka-Bórawska i in. (2015).

Nasiona roślin oleistych i oleju roślinnego odgrywają ważną rolę w gospodarce żywnościowej i w przemyśle. Stanowią surowiec do produkcji tłuszczy konsumpcyjnych, technicznych i biopaliw oraz są źródłem białka spożywczego i paszowego (Budzyński i Zając 2010). Według Denesiuk (2006) nowe osiągnięcia biotechnologii zwiększają możliwości ich zastosowania (farmaceutyki, kosmetyki, farby, emulgatory, i inne). Dynamiczny rozwój produkcji biodiesla w Europie i wzrost zapotrzebowania na olej rzepakowy do wytwarzania estrów spowodował prawie dwukrotny wzrost produkcji rzepaku w krajach UE (Rosiak 2008).

Wśród roślin oleistych w Unii Europejskiej szczególne znaczenie mają rzepak, soja i słonecznik.

\section{MATERIA I METODA}

Główną metodą badawczą w tym opracowaniu są modele ekonometryczne. Natomiast hipoteza, która będzie weryfikowana w pracy, mówi, że ekonometryczne modele mogą być użytecznym narzędziem wspomagającym ustalanie wpływu czynników podażowo-popytowych na cenę wybranych produktów rolno-żywnościowych.

Empiryczną podstawę badań stanowią dane OECD i FAO (Agricultural outlook 2016) z lat 2004-2016 dotyczące UE:

- średnie arytmetyczne cen skupu nasion roślin oleistych, w euro/t $\left(y_{1 t}\right)$;

- średnie arytmetyczne cen producenta oleju roślinnego, w euro/t $\left(y_{2 t}\right)$;

- powierzchnia zasiewu roślin oleistych, w ha $\left(x_{1 t}\right)$;

- średnie arytmetyczne plonów roślin oleistych, w dt/ha $\left(x_{2 t}\right)$; 
- eksport, w tys. $t\left(x_{3 t}\right)$;

- import nasion roślin oleistych, w tys. $t\left(x_{4 t}\right)$;

- zbiory roślin oleistych, w tys. $t\left(x_{5 t}\right)$;

- eksport, w tys. $t\left(x_{6 t}\right)$;

- import oleju roślinnego, w tys. $t\left(x_{7 t}\right)$;

- produkcja oleju roślinnego, w tys. t $\left(x_{8 t}\right)$;

- średnie arytmetyczne spożycie oleju roślinnego na mieszkańca, w kg ( $\left.x_{9 t}\right)$;

- zużycie oleju roślinnego ogółem, w $t\left(x_{10 t}\right)$.

O wstępnym doborze zmiennych zadecydowała głównie znajomość teorii ekonomii i dostępność danych. $\mathrm{Na}$ ich podstawie, za pomocą wielorównaniowego modelu ekonometrycznego, badano wpływ czynników podażowo-popytowych na cenę nasion roślin oleistych i oleju roślinnego na rynkach UE.

Ekonometryczny wielorównaniowy model uwzględniający wszystkie zmienne ma postać:

$$
\begin{aligned}
& y_{1 t}=\alpha_{10}+\alpha_{11} x_{1 t}+\alpha_{12} x_{2 t}+\alpha_{13} x_{3 t}+\alpha_{14} x_{4 t}+\alpha_{15} x_{5 t}+\alpha_{16} x_{6 t}+\alpha_{17} x_{7 t}+\alpha_{18} x_{8 t}+u_{1 t} \\
& y_{2 t}=\alpha_{20}+\alpha_{21} y_{1 t}+\alpha_{22} x_{5 t}+\alpha_{23} x_{6 t}+\alpha_{24} x_{7 t}+\alpha_{25} x_{8 t}+\alpha_{26} x_{9 t}+\alpha_{27} x_{10 t}+u_{2 t}
\end{aligned}
$$
gdzie:

$\alpha_{i j}$ - parametry strukturalne modelu dla $i$-tego równania i j-tej zmiennej,

$u_{i t}-$ składnik losowy.

Zbudowana macierz parametrów występujących przy zmiennych endogenicznych nieopóźnionych w czasie:

$$
\mathbf{A}=\left[\begin{array}{cc}
1 & 0 \\
-\alpha_{21} & 1
\end{array}\right]
$$

Jest to macierz trójkątna, a więc skonstruowany model jest modelem rekurencyjnym. Jego parametry strukturalne można oszacować klasyczną metodą najmniejszych kwadratów (KMNK) - Welfe (2009).

Estymacja parametrów została poprzedzona wyznaczeniem współczynników korelacji pomiędzy zmiennymi, aby wykluczyć z modelu zmienne skorelowane, powodujące powielanie informacji o badanych cenach. Wysokie współczynniki korelacji pomiędzy potencjalnymi zmiennymi objaśniającymi $\left(x_{1 t}, x_{5 t}, x_{7 t}, x_{8 t}, x_{10 t}\right)$ zadecydowały o wyeliminowaniu ich z modelu. Tabele 1 i 2 przedstawiają współczynniki korelacji pomiędzy zmiennymi, które dostarczają najwięcej informacji o cenie nasion roślin oleistych i oleju roślinnego.

Tabela 1. Współczynniki korelacji pomiędzy ceną nasion roślin oleistych a ich plonem, eksportem i importem

\begin{tabular}{|l|c|c|c|c|}
\hline Zmienne & $y_{1 t}$ & $x_{2 t}$ & $x_{3 t}$ & $x_{4 t}$ \\
\hline$y_{1 t}$ & 1 & $-0,2861$ & 0,2133 & $-0,5764$ \\
\hline$x_{2 t}$ & $-0,2861$ & 1 & $-0,4462$ & 0,2206 \\
\hline$x_{3 t}$ & 0,2133 & $-0,4462$ & 1 & $-0,1183$ \\
\hline$x_{4 t}$ & $-0,5764$ & 0,2206 & $-0,1183$ & 1 \\
\hline
\end{tabular}

Tabela 2. Współczynniki korelacji pomiędzy ceną oleju roślinnego, a ceną nasion roślin oleistych, eksportem i spożyciem oleju roślinnego przez 1 mieszkańca

\begin{tabular}{|l|c|c|c|c|}
\hline Zmienne & $y_{2 t}$ & $y_{1 t}$ & $x_{6 t}$ & $x_{9 t}$ \\
\hline$y_{2 t}$ & 1 & 0,9258 & 0,5439 & $-0,7869$ \\
\hline$y_{1 t}$ & 0,9258 & 1 & 0,4786 & $-0,8448$ \\
\hline$x_{6 t}$ & 0,5439 & 0,4786 & 1 & $-0,3379$ \\
\hline$x_{9 t}$ & $-0,7869$ & $-0,8448$ & $-0,3379$ & 1 \\
\hline
\end{tabular}


Model o ograniczonej liczbie zmiennych egzogenicznych ma postać:

$y_{1 t}=\alpha_{10}+\alpha_{12} x_{2 t}+\alpha_{13} x_{3 t}+\alpha_{14} x_{4 t}+u_{1 t}$

$y_{2 t}=\alpha_{20}+\alpha_{21} y_{1 t}+\alpha_{23} x_{6 t}+\alpha_{26} x_{9 t}+u_{2 t}$

Model ten pozwala na analizę cen nasion roślin oleistych i oleju roślinnego $\mathrm{w}$ latach 2004-2016.

Natomiast do badania kierunku zmian i prognozowania cen nasion roślin oleistych i olej roślinnego w latach 2017-2018 wykorzystano modele trendu (Zeliaś 2003):

$y_{t}=f(t)+\varepsilon_{t}$

gdzie:

$y_{t}$ - cena produktów rolno-żywnościowych w badanym okresie,

$f(t)$ - funkcja trendu (np. wielomian liniowy lub wykładniczy stopnia pierwszego, drugiego lub trzeciego),

$t$ - zmienna czasowa $(t=1,2, \ldots, n)$,

$\varepsilon_{t}-$ składnik losowy.

\section{WYNIKI}

Parametry strukturalne i struktury stochastycznej rekurencyjnego modelu wielorównaniowego zostały oszacowane KMNK. Cenę roślin oleistych najdokładniej opisywał model liniowo-potęgowy $\left(R^{2}=0,5965\right)$, a cenę oleju roślinnego - model liniowo-wykładniczy $\left(R^{2}=0,9785\right)^{1}$. Wyniki estymacji przedstawia tab. 3.

Tabela 3. Parametry modelu wielorównaniowego

\begin{tabular}{|c|c|c|c|}
\hline \multirow[b]{2}{*}{$\begin{array}{l}\text { Zmienne } \\
\text { objaśniające }\end{array}$} & \multicolumn{3}{|c|}{ Zmienna objaśniana Iny1t; } \\
\hline & parametry strukturalne & $\begin{array}{l}\text { statystyka } \\
\text { T-Studenta }\end{array}$ & parametry struktury stochastycznej \\
\hline $\begin{array}{l}\text { Wyraz wolny } \\
\ln x_{2 t} \\
\ln x_{3 t} \\
\ln x_{4 t}\end{array}$ & $\begin{array}{r}6,7939 \\
-2,0833 \\
0,3881 \\
-0,4090\end{array}$ & $\begin{array}{r}2,3955 \\
-2,5603 \\
2,0902 \\
-4,3247\end{array}$ & $\begin{array}{l}R^{2}=0,5965 \\
S e=0,1608 \\
V_{S}=0,2751\end{array}$ \\
\hline \multicolumn{4}{|c|}{ Zmienna objaśniana $\ln y 2 t$} \\
\hline $\begin{array}{l}\text { Wyraz wolny } \\
y_{1 t} \\
x_{6 t} \\
x_{9 t}\end{array}$ & $\begin{array}{l}5,0413 \\
0,0031 \\
0,0002 \\
0,0257\end{array}$ & $\begin{array}{r}13,1288 \\
14,4084 \\
7,3306 \\
2,0618\end{array}$ & $\begin{array}{l}R^{2}=0,9785 \\
S e=0,0308 \\
V_{S}=0,0047\end{array}$ \\
\hline
\end{tabular}

$R^{2}$ - współczynnik determinacji, Se - odchylenie standardowe, $V_{s}$ - współczynnik zmienności.

Wszystkie parametry strukturalne modelu są istotne statystycznie, co potwierdza wartość statystyki T. Cena skupu nasion roślin oleistych zależała głównie od importu nasion i plonów. Natomiast na cenę oleju roślinnego duży wpływ miała cena skupu roślin oleistych i eksport oleju. Z dokładnej interpretacji parametrów strukturalnych modelu wynika, że:

- wzrost plonów o 1\% spowoduje obniżenie ceny nasion roślin oleistych o 2,08\%,

- wzrost eksportu nasion roślin oleistych o 1\% zwiększy cenę tych nasion o około $0,39 \%$,

- wzrost importu nasion roślin oleistych o 1\% zmniejszy ich cenę o około 0,41\%,

- wzrost ceny nasion roślin oleistych o 1euro/t spowoduje wzrost ceny oleju roślinnego o $0,31 \%$,

\footnotetext{
${ }^{1}$ Dla każdego równania oszacowano modele liniowy, liniowo-wykładniczy i liniowo-potęgowy.
} 
- wzrost eksportu oleju roślinnego o 1 tys. t podwyższy jego cenę o 0,02\%;

- wzrost spożycia oleju roślinnego przez jednego mieszkańca UE o 1 kg zwiększy jego cenę o $2,57 \%$.

Interpretacje te są właściwe przy zachowaniu stałości pozostałych zmiennych objaśniających w modelu.

Zarówno odchylenie standardowe (16,08\%), jak i współczynnik zmienności $(27,51 \%)$ pierwszego równania modelu wskazują na stosunkowo duże odchylenie wartości teoretycznych od wartości empirycznych, co potwierdza również ryc. 1.

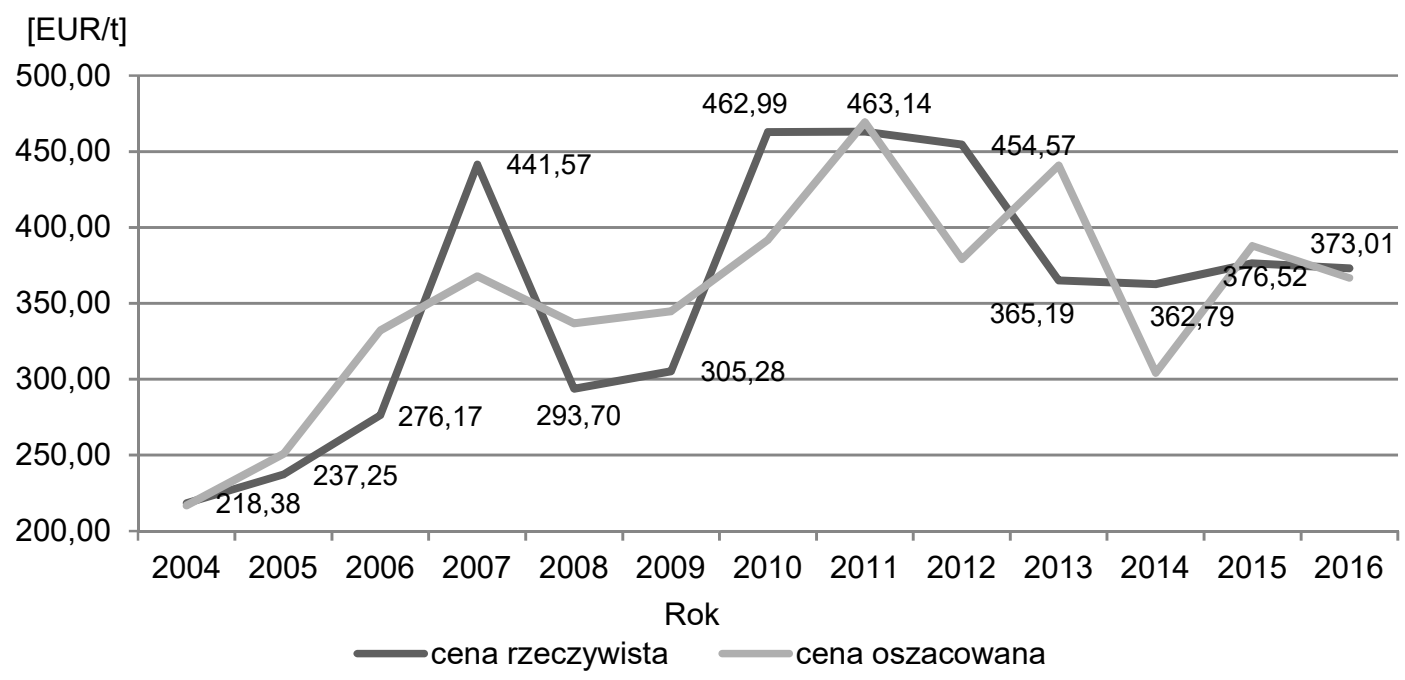

Ryc.1. Ceny roślin oleistych w UE w latach 2004-2016

Źródło: opracowano na podstawie danych OECD i FAO (Agricultural outlook 2016).

Natomiast ceny oleju roślinnego, oszacowane za pomocą drugiego równania modelu, tylko nieznacznie $\left(S_{e}=3,08 \%\right)$ różnią się od cen rzeczywistych (ryc. 2$)$.

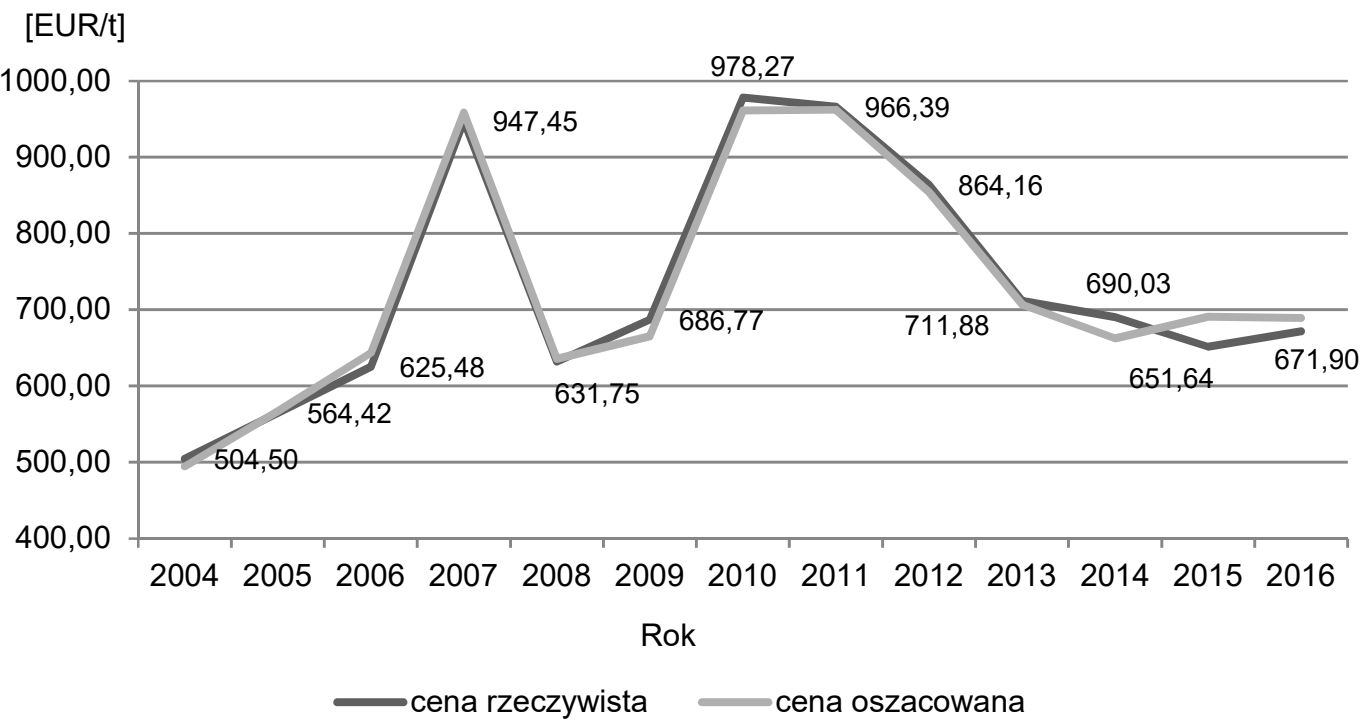

Ryc. 2. Ceny oleju roślinnego w UE w latach 2004-2016

Żródło: patrz ryc 1. 
Na wykresach wyraźnie zaznaczył się gwałtowny wzrost cen zarówno roślin oleistych, jak i oleju roślinnego w roku 2007 oraz w latach 2010-2012. Potwierdza to ścisłą zależność cen oleju od cen roślin oleistych. Według ekspertów (Dudziński 2009; De Schutter 2010) do kryzysu żywnościowego w tych latach przyczyniły się głównie czynniki o charakterze strukturalnym i koniunkturalnym, które są ściśle związane z czynnikami podażowo-popytowymi. Wzrost zapotrzebowania na biopaliwa ograniczył przeznaczanie nasion roślin oleistych na żywność (produkcję oleju). Kraje, chcąc ograniczyć wzrost cen żywności na rynku wewnętrznym, ograniczały eksport. Efektem tego było zmniejszenie podaży na rynkach zewnętrznych i wzrost cen.

Kierunki zmian cen nasion roślin oleistych i oleju roślinnego w czasie analizowano za pomocą liniowych i wykładniczych funkcji trendu. Wyniki oszacowań, uzyskane dla wykładniczych modeli trendu stopnia drugiego, charakteryzowały się najwyższym stopniem opisu (tab. 4).

Tabela 4. Oszacowania trendów i prognozy

\begin{tabular}{|c|c|c|c|c|}
\hline \multirow{2}{*}{$\begin{array}{l}\text { Zmienna objaśniana - } \\
\text { ceny producenta (EUR/t) }\end{array}$} & \multirow{2}{*}{$\begin{array}{c}\text { Trend } \\
\text { (wartości statystyk T) }\end{array}$} & \multirow{2}{*}{$\begin{array}{l}\text { Parametry struktury } \\
\text { stochastycznej }\end{array}$} & \multicolumn{2}{|c|}{$\begin{array}{l}\text { Prognozy cen } \\
\text { (EUR/t) }\end{array}$} \\
\hline & & & 2017 r. & $2018 \mathrm{r}$. \\
\hline Nasiona roślin oleistych & $\begin{array}{r}\ln y_{t}=5,2002+0,1862 t-0,0104 t^{2} \\
(33,19) \quad(3,62) \quad(-2,91)\end{array}$ & $R^{2}=0,60, S_{e}=0,16$ & 320,09 & 285,20 \\
\hline Olej roślinny & $\begin{aligned} \ln y_{t}= & 6,0607+0,1758 t-0,0112 t^{2} \\
& (41,51) \quad(3,66) \quad(-3,42)\end{aligned}$ & $R^{2}=0,58, S_{e}=0,15$ & 625,27 & 581,88 \\
\hline
\end{tabular}

Źródło: obliczono na podstawie danych OECD-FAO (Agricultural outlook 2016).

Trendy wykładnicze stopnia drugiego opisywały rzeczywiste wahania cen nasion roślin oleistych i oleju roślinnego w czasie odpowiednio w 60\% i 58\%, a wartości oszacowane tych cen odchylały się od empirycznych średnio o 16\% i 15\%.

Prognozy przewidują obniżenie cen analizowanych produktów rolno-spożywczych w latach 2017-2018, co dokładnie obrazuje ryc. 2.

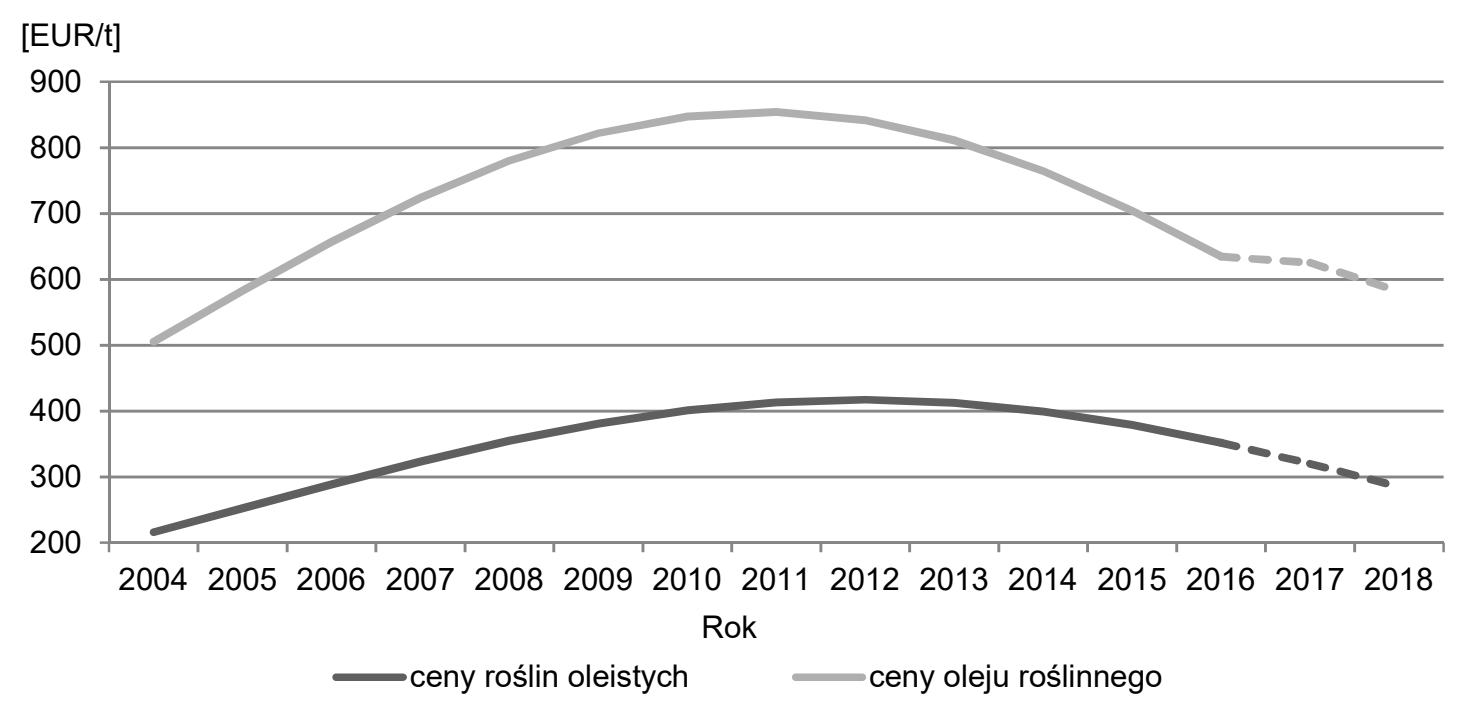

Ryc. 3. Ceny nasion roślin oleistych i oleju roślinnego wyznaczone na podstwie trendów oraz ich prognozy na lata 2017-2018

Źródło: patrz ryc 1. 
Ceny roślin oleistych wyznaczone na podstawie trendu do roku 2012 wykazywały tendencję wzrostową, a w kolejnych latach malały. Oszacowane ceny oleju roślinnego gwałtownie wzrastały do roku 2011; po tym okresie kierunek trendu zmienił się na malejący. Początkowy wzrost cen był efektem kryzysu żywnościowego. Prognozy na lata 2017-2018 przewidują dalszy spadek cen nasion roślin oleistych i oleju roślinnego w Unii Europejskiej.

Otrzymane wyniki są zgodne z wynikami badań innych autorów oraz potwierdzają przyjętą hipotezę badań. Z analiz przeprowadzonych przez Kiryluk-Dryjską i Baer-Nawrocką (2010) wynika, że w wybranych krajach UE występuje tendencja do obniżania cen produktów rolnych, przy jednocześnie zmniejszającej się ich zmienności. Natomiast według Hamulczuka i in. (2012) światowa nadprodukcja żywności oraz tanie surowce wpływają na obniżanie cen produktów rolno-spożywczych, jednak w perspektywie długoterminowej (do roku 2021) ceny nieznacznie wzrosną. Do wzrostu cen w UE mogą przyczynić się rosnąca liczba ludności, poprawa jakości żywienia, rozwój biopaliw oraz nowoczesne technologie żywienia zwierząt oparte na śrucie z roślin oleistych (Rosiak 2014).

\section{PODSUMOWANIE}

Z przeglądu literatury (Rembisz 2008; Ziętara 2008; Hamulczuk i in. 2012) i analizy danych statystycznych wynika, że w latach 2004-2016 ceny nasion roślin oleistych i oleju roślinnego wykazywały dużą zmienność. Przyczyn tych zmian należy doszukiwać się wśród czynników podażowo-popytowych, strukturalnych i koniunkturalnych.

W pracy za pomocą wielorównaniowego modelu ekonometrycznego badano wpływ czynników podażowo-popytowych (które są ściśle związane z czynnikami strukturalnymi i koniunkturalnymi), na cenę nasion roślin oleistych i oleju roślinnego w UE. Czynniki te dotyczyły produkcji nasion roślin oleistych i oleju roślinnego, konsumpcji oleju roślinnego oraz handlu zagranicznego zarówno nasionami roślin oleistych, jak i olejem roślinnym w UE w latach 2004-2016.

Z przeprowadzonych badań wynika, że ceny roślin oleistych w latach 2004-2016 zależały głównie od importu nasion i plonów tych roślin. Na podstawie pierwszego równania modelu można stwierdzić, że: wzrost plonów o 1\% spowoduje obniżenie ceny nasion roślin oleistych o 2,08\%, wzrost eksportu nasion roślin oleistych o $1 \%$ zwiększy cenę tych nasion o około $0,39 \%$, a wzrost importu nasion roślin oleistych o $1 \%$ zmniejszy ich cenę o około $0,41 \%$.

Z oszacowań drugiego równania modelu wynika, że: wzrost ceny nasion roślin oleistych o 1 euro/t spowoduje wzrost ceny oleju roślinnego o 0,31\%, wzrost eksportu oleju roślinnego o 1 tys. $t$ podwyższy jego cenę o $0,02 \%$, a wzrost spożycia oleju roślinnego przez jednego mieszkańca UE o $1 \mathrm{~kg}$ zwiększy jego cenę o 2,57\%.

Na przedstawionych wykresach (ryc. 1,2) ceny nasion roślin oleistych i oleju roślinnego w latach 2004-2016 wykazywały dużą zmienność. Wyraźnie uwidocznił się też gwałtowny ich wzrost w roku 2007 i w latach 2010-2012, co znajduje potwierdzenie w literaturze (Stępień 2011).

W celu zbadania kierunku zmian cen nasion roślin oleistych i oleju roślinnego oraz wyznaczenia ich prognoz oszacowano modele trendów. Najlepiej dopasowane do danych empirycznych były trendy wykładnicze stopnia drugiego. $Z$ ich analizy wynika, że ceny roślin 
oleistych wzrastały do roku 2012, a oleju roślinnego - do roku 2011. W następnych latach ceny wykazywały tendencję malejącą. Oszacowane prognozy na lata 2017-2018 wskazują na dalszy spadek cen nasion roślin oleistych i oleju roślinnego w UE.

Na podstawie przeprowadzonych badań można stwierdzić, że modele ekonometryczne można wykorzystać jako narzędzie wspomagające ustalanie wpływu czynników podażowo-popytowych na cenę produktów rolno-żywnościowych, co potwierdza przyjętą hipotezę badań.

\section{PIŚMIENNICTWO}

Baffes J., Dennis A. 2013. Long-term drivers of food prices. Policy Res. Work. Pap. Washington D.C. 6455.

Bełdycka-Bórawska A., Bórawski P., Jankowski K. 2015. Zmienność cen na rynku rzepaku w Polsce. Rocz. Nauk Rol., Seria T 17(3), 57-43.

Budzyński W., Zając T. 2010. Rośliny oleiste - uprawa i zastosowanie. Warszawa, PWRiL.

Denysiuk W. 2006. Produkcja roślinna jako źródło surowców energetycznych. Inż. Rol. 10, 5(80), 123-250.

De Schutter O. 2010. Food commodities speculation and food price crises. Regulation to reduce the risks of price volatility. Briefing note by the Special Rapporteur on the right to food, U.N. Food and Agriculture Organization, http://www.srfood.org/en/food-commodities-speculation- and-food-price-crises, dostęp: 10.08.2017.

Dudziński J. 2010. Długookresowe tendencje cen surowców i żywności w świetle prognozy Banku Światowego. Stud. Pr. Wydz. Nauk Ekon. Zarz. 18,17-33.

Hajdukiewicz A. 2014. Przyczyny wzrostu światowych cen produktów rolno-spożywczych w pierwszej dekadzie XXI wieku. Pr. Nauk. UWroc. 369, 239-250.

Hamulczuk M., Gędek S., Klimowski C., Stańko S. 2012. Prognozowanie cen surowców rolnych na podstawie zależności przyczynowych. Projekt nr 52, Warszawa, Wydaw. IERiGŻ-PIB.

Jerzak M.A., Łąkowski H.S. 2013. Towarowe instrumenty pochodne w stabilizowaniu dochodów z produkcji rzepaku w warunkach rosnącego ryzyka cenowego. Zesz. Nauk. SGGW Warsz., Ekonomika i Organizacja Gospodarki Żywnościowej 103, 131-140.

Kiryluk-Dryjska E., Baer-Nawrocką A. 2010. Wpływ akcesji do Unii Europejskiej na poziom i relacje cenowe w rolnictwie polskim (analiza długookresowa). Zesz. Nauk. SGGW Warsz., Ekonomika i Organizacja Gospodarki Żywnościowej 85, 59-67.

Miegel M. 2008. Granice wzrostu. Forum 9, 21-23.

OECD-FAO. 2016. Agricultural outlook, http://www.oecd.org/site/oecd-fao-agriculturaloutlook, dostęp: 10.04.2017.

Rembisz W. 2008. Makro-i mikroekonomiczne podstawy równowagi wzrostu w sektorze rolnospożywczym. Warszawa, Wydaw. VIZJAPRESS\&IT.

Rosiak E. 2008. Wzrost produkcji biopaliw z olejów roślinnych. Przem. Spoż. 62(1), 14-15

Rosiak E. 2014. Krajowy rynek rzepaku na tle rynku światowego. Zesz. Nauk. SGGW Warsz., Probl. Rol. Świat. 14(29), 86-96.

Schmitz M. 2013. Biofuel's impact on food prices should be put into perspective, European Voice, http://www.europeanvoice.com/article/imported/biofuel-s-impact-on-food-pricesshould-be-put-intoperspective/77678.aspx, dostęp: 15. 04.2017.

Stępień S. 2011. Związki wahań cyklicznych w rolnictwie z koniunkturą gospodarczą. Rocz. Nauk Rol., Seria T 98(3), 32-41.

Welfe A. 2009. Ekonometria. Metody i ich zastosowanie. Warszawa, PWE.

Zawojska A. 2011. Czy spekulacje finansowe wpływają na międzynarodowe ceny towarów rolno-żywnościowych? Zesz. Nauk. SGGW Warsz., Probl. Rol. Świat. 11(26), 177-191. 
Zeliaś A., Wanat S., Pawełek B. 2003. Prognozowanie ekonomiczne. Warszawa, PWN.

Ziętara W. 2008. Wewnętrzne uwarunkowania rozwoju polskiego rolnictwa. Rocz. Nauk Rol., Seria G 94(2), 80-94.

Streszczenie. Ceny produktów rolno-spożywczych na rynkach Unii Europejskiej kształtują czynniki podażowo-popytowe, strukturalne i koniunkturalne. Celem tego opracowania jest określenie wpływu czynników podażowo-popytowych na cenę skupu nasion roślin oleistych i oleju roślinnego w Unii Europejskiej oraz wyznaczenie kierunku rozwoju tych cen. Realizację tego celu umożliwił wielorównaniowy model ekonometryczny. Za pomocą trendów wyznaczono kierunki rozwoju cen analizowanych produktów rolno-spożywczych i oszacowano ich prognozy. Empiryczną podstawę badań stanowiły dane OECD i FAO w latach 2004-2016. Wyniki badań wykazały wysoką zależność pomiędzy ceną wybranych produktów a czynnikami związanymi z produkcją, konsumpcją i handlem zagranicznym. Natomiast z oszacowań trendów wynika, że ceny tych produktów do roku 2011/2012 wzrastały, a po tym okresie wykazywały tendencję malejącą. Prognozy przewidują dalszy spadek cen. 
